\title{
Reflections on the Training of University Students' Legal Literacy
}

\author{
Lianxiang Liu \\ Nanyang Institute of Technology \\ Nanyang, China 473004
}

\begin{abstract}
Legal literacy is an integral part of the overall quality of contemporary college students. Having good legal literacy is not only beneficial to improve the comprehensive quality of college students, but also to the construction of the rule of law and the realization of the Chinese dream. To cultivate students' legal literacy first to reform education, attach importance to legal courses in the basic role of improving students' legal literacy, secondly to strengthen the socialist idea of rule of law propaganda, let students have a legal identity, from the deep end, the campus to the rule of law, an exemplary role for the cultivation of College Students' legal literacy.
\end{abstract}

Keywords-Legal literacy; value of the times; ways of cultivation

\section{INTRODUCTION}

In 1997 the 15th Party Congress formally put forward the basic strategy of "rule of law", in March 1999, the two meeting of the nine national people's Congress constitutional amendment stipulates: "People's Republic of China implementation of the rule of law and building a socialist country ruled by law". In 2014, the party in the fourth Plenary Session of the 18th CPC Central Committee studied a number of major issues of promoting the rule of law in an all-round way, and carried out overall plans and overall plans for the rule of law. The rule of law has become the main theme of the times, and college students as the successors of socialism, as the backbone of the great rejuvenation of the Chinese nation Chinese dream, legal literacy of university students not only reflect the students' personal comprehensive quality, it is a reflection of social and national civilization.

\section{ThE VAlue OF THE Times to Cultivate THE LeGAL LITERACY OF COLLEGE STUDENTS}

\section{A. Having Good Legal Literacy Is the Need to Improve} Their Comprehensive Quality

In the new period, college students need good legal literacy to improve their comprehensive quality. The traditional single exam oriented education model has been unable to meet the requirements of the times, and the value of comprehensive quality education has become increasingly prominent. To help college students establish a rational spirit, the rule of law, can make students in thinking of people doing things more calm and rational and facing various problems; learn to understand and respect for others; it less instinctive impulse, more rational thinking, know what can be, what not to, also can make students form good habits in accordance with the law act. In civilized society, the law as a major norm of behavior is everywhere, and closely related to our production and life. As a qualified university student, we should either directly or indirectly resort to the law when the rights are violated.

\section{B. Having Good Legal Literacy Is the Inevitable}

Requirement of Ruling the Country by Law

Ruling the country by law is the essential requirement and important guarantee for adhering to and developing socialism with Chinese characteristics. It is an inevitable requirement for the realization of the modernization of the national governance system and governance capability. Building a well-off society and realize the great rejuvenation of the Chinese nation China dream, deepen reform, improve and develop the socialist China system, improve the party's ruling ability and the ruling level, we must comprehensively promote the rule of law. In the fourth Plenary Session of the 18th CPC Central Committee, the party studied the important issues of administering the country according to law. College students are the main force of national construction, Chinese future social development lies in the hands of contemporary college students' legal literacy, determines whether countries can achieve the rule of law, legal literacy of college students also determines the national revival of hope, Chinese society go to the rule of law is the hope of College students. Therefore, college students have good legal literacy and play a very important role in promoting the rule of law.

\section{With Good Legal Literacy Is to Ensure the Realization of the Chinese Dream}

"To realize the great rejuvenation of the Chinese nation is the greatest dream of the Chinese nation since modern times," the general secretary put forward by the Chinese dream, so that everyone in China is moved, and the university students are no exception. University students, as the backbone of the great rejuvenation of the Chinese nation, must have good legal literacy, and only when they have good legal literacy can they participate in the construction of the Chinese dream better. The Chinese dream is the dream of the nation, the dream of the people, and the dream of the University students. Therefore, students' legal literacy training, so that students study the law, law, law, which is the foundation and guarantee to realize the dream of China. 


\section{THE CURRENT UNIVERSITY STUDENTS' LEGAL LITERACY PROBLEMS}

Legal literacy refers to the ability of a person to recognize and apply the law. One refers to legal knowledge, two is legal awareness, legal concept, and three is legal belief. In order to have an objective evaluation of the legal literacy of college students, and to explore ways to cultivate students' legal education and legal literacy, the author makes a questionnaire survey of university students' legal literacy.

\section{A. Lack of Legal Knowledge}

A total of 500 questionnaires were issued, 452 questionnaires were returned and 435 questionnaires were valid, with an effective rate of $96.23 \%$. The main way to learn legal knowledge for non law majors is through the ideological and moral cultivation and the legal basis. According to the survey, only $12.3 \%$ of the students that can learn from the course to legal knowledge, while $57.7 \%$ of the students thought that the creation of their legal knowledge to improve usefulness of this course, $30 \%$ of the students thought that the course of no great importance, can not even learn this course. As can be seen from these data, college students have limited access to legal knowledge, while the limited access to the legal knowledge of the real knowledge of very few.

\section{B. The Legal Consciousness Is Weak}

Asked what kind of measures would be taken when the rights and interests were infringed when they bought fake and shoddy products. Only $22.5 \%$ of college students chose to seek legal or legal solutions. $67.3 \%$ of college students chose other ways to solve them, and $10.2 \%$ of college students admitted to bad luck. This survey data shows that college students have a weak sense of rights protection, and when their legitimate rights and interests are infringed, they do not know how to protect themselves with legal weapons. Then to the social level, the proportion of college students crime is on the rise. Such as the 2002 Tsinghua University student Liu Haiyang with acid bear, 2004 Yunnan University students brutally killed 4 students Majiajue incident, Yao events in 2010, 2013 in Fudan University poisoning. Behind the problem of college students crime is the weak law consciousness of College students.

\section{Lack of Legal Belief}

Berman, a famous American jurist, said, "the law must be believed, otherwise it will be in name only."". So what is faith in law? In my opinion, the legal belief should be a convincing identification and acknowledgement of law, people's rational feelings of law and consciousness of psychological factors such as organic synthesis, the method is rational and the passion of sublimation, is the main method of subjective psychological state by state. According to the survey, $80.4 \%$ of college students is the identity of the law, they think the law on safeguarding social fairness and justice has played a crucial role in the law of China's socialist modernization construction and China dream has a huge role. However, the reality has to make us think why the legal literacy of contemporary college students is still poor

\section{EFFECTIVE WAYS TO CULTIVATE UNIVERSITY STUDENTS' LEGAL LITERACY}

\section{A. To Promote Educational Reform and Strengthen the Construction of the Legal Curriculum}

The current legal system in Colleges and universities still exist many unreasonable, and the basic law courses as popularize legal knowledge, cultivate and improve the students' legal literacy key channels, so to promote the reform of the basic course of law "imperative. First of all, legal literacy is not equal to the legal knowledge, nor legal achievement, students learning the meaning of law is not to a final exam papers, not for the final exam score, this is the examination oriented education mode, the contemporary college students should frame the exam oriented education, the basic course of law, but also to overcome such drawbacks. "Knowledge of legal knowledge only shows how well it understands legal thought and the legal system, and how well it is familiar with the law.". The cultivation of legal awareness is a comprehensive project, not merely measured by the degree of mastery of legal knowledge." [3] the cultivation of legal literacy is a comprehensive project, and the basic law course is the cornerstone of this project. The role of the cornerstone of the legal foundation needs to change from the established pattern of education. The teacher's teaching methods should be flexible, able to attract the interest of students, make students become the subjects of the curriculum, and actively guide students to think, analysis of the teacher can be introduced in the course of the real case, to create a lively and vivid classroom, let the students into the classroom, into the law of knowledge learning.

\section{B. Strengthen the Propaganda of Socialist Rule of Law}

The eighteen Party Congress "advocated a prosperous, democratic, civilized and harmonious, advocating freedom, equality, justice, rule of law, advocate patriotism, dedication, integrity, kindness, and actively cultivate and practice the socialist core values." Among them, the "rule of law" as a social level has been put forward, reflecting the building of a rule of law society has become the common aspiration of the people. In order to cultivate and improve the students' legal literacy, the society should create a legal environment, there is a social and ideological basis, to contemporary college students from the heart of the legal identity, have a basic sense of identity, students can consciously cultivate internal legal literacy. To strengthen the socialist idea of rule of law publicity should be the following two aspects: first, make good use of the network and the plane of the power of the media, this is an era of information, network has immeasurable strength, we need to play a positive role in the network, I think we can create special propaganda of legal thought website, making propaganda on the network legal system excellent program. Magazines, newspapers and other print media coverage of society is relatively wide, many college students have the habit of reading newspapers and magazines, so you can set up a "rule of China" column in the newspaper to publicize the socialist idea of rule of law. Second, to exert the influence of Library in students, the library as the "second classroom" is the main place for extracurricular activities of college students. It is the best potential classroom in itself. University library is also an 
important part of campus culture and an important position in the construction of campus culture. So, the author suggests that universities can make excellent "legal thought tabloid" in the library of the display, the idea of rule of law as an important part of the construction of campus culture, it can let students feel the "rule of law" is on our side.

\section{Strengthen the University Campus Management According to Law}

The management system for college students' understanding of the actual law of the most direct and sensitive is from the university itself, whether the management system of colleges and universities is really in line with the rule of law, for college students to set up the legal belief in the practice of the most direct experience of [4], as a college student life and learning of the subject, the university should be an exemplary role for the cultivation of College Students' legal literacy the. Schools should first be governed by law, and the management systems of schools must be in strict accordance with the prescribed system, and there must be no policy decisions that impede democracy. Secondly, the school should encourage the students to express their views for the rule of law, allow students to participate in school management, improve students' enthusiasm and participation in the rule of law, will be on the cultivation of College Students' legal literacy plays an important role.

\section{CONCLUSION}

The legal quality of college students is still at a relatively poor level, cultivate students' legal literacy and urgent work, level of the college students' legal literacy will directly affect the rule of law and realize the great rejuvenation of the Chinese dream China process. Let each of our college students to start from their own every little bit, consciously cultivate and improve the legal quality of its own, for the construction of a socialist country ruled by law and realize the great rejuvenation of the Chinese nation gave himself a force.

\section{REFERENCES}

[1] Xinhua, the CPC Central Committee on the decision to comprehensively promote the rule of law, a number of major issues, [DB/OL]. http://news.xinhuanet.com/2014-10/28/c_1113015330.htm, October 28, 2014

[2] Zhang pan. Some reflections on improving the legal literacy of college students $[\mathrm{J}]$. school party building and ideological education, 2016, (10)

[3] Jiang Bo, Chen Tao. Cultivation of College Students' legal literacy based on the construction of the rule of law [J]. Journal of Hebei University (PHILOSOPHY AND SOCIAL SCIENCES), 2015 (6)

[4] Zhang Dafang. Construction of university students' Legal Belief Cultivation System [J]. legal system Expo, 2014, (2) 